International Journal of Linguistics, Literature and Translation

ISSN: 2617-0299 (Online); ISSN: 2708-0099 (Print)

DOI: $10.32996 / \mathrm{ijllt}$

Journal Homepage: www.al-kindipublisher.com/index.php/ijltt

IJLLT

\title{
The Functions of the Haunting Ghost Ben in Death of a Salesman
}

\author{
Hu Yaping \\ Associate professor of Xianda Economic and Humanistic College, Shanghai International Studies, China \\ Corresponding Author: Hu Yaping, E-mail: 0810190@xdsisu.edu.cn
}

\author{
ARTICLE INFORMATION \\ Received: September 18, 2021 \\ Accepted: October 15, 2021 \\ Volume: 4 \\ Issue: 10 \\ DOI: $10.32996 /$ ijllt.2021.4.10.2
}

\section{ABSTRACT}

Arthur Miller's masterpiece Death of a Salesman received a large number of papers, but few specially analyze "Ben", a mysterious figure who frequently appears in Willie Loman's illusion. This article aims to study the reasons and functions of his appearances and finds that he is only the projection of his brother Willy's consciousness and his words are used by Willy to justify his activities, including his suicide.

\section{KEYWORDS}

Death, appearance, success, ghost

Gary Harrington claims that in Arthur Miller's Death of a Salesman, Willy Loman's life teems with ghosts. Prominent among these is the ghost of his older brother, Ben, with whom Willy converses at key points in the play, and most importantly, in the garden late on the evening of Willy's suicide (Garry 2006). In the play, his elder brother Ben is the only one in the world that Willy can unburden himself and Ben appears when Willy is desperate and searching for an answer. Ben appears four times and they have four conversations.

The first time Ben appears is in Act One when Willy is playing cards with Charley (186). From the conversation, the information about their father is revealed to Willy, but their father leaves when Willy is only three years and eleven months. Therefore, Ben acts as a more concrete image in Willy's mind to tell him how to be successful as fathers do to their sons. Fred Ribkoff agrees that in fact, his elder brother, Ben, becomes the measure of success and manhood for his sons to live up to because Willy is abandoned at the age of three by his father (Fred 2000). Ben tells Willy that he walks into the jungle at 17 and walks out at 21 and he is rich. So Ben is, in Willy's own words, the only man he ever meets who knows the answers. Willy would like his brother to offer some advice on teaching his boys to be successful. Ben says to Willy he has never kept books but he has many enterprises (189), and Ben teaches Biff never to fight fair with a stranger (190). Ben's teaching serves as guiding rules to Willy who is always searching for the secret to success and he raises his own sons just in this way. "That's just the way l'm bringing them up, Ben---- rugged, wellliked, all-round"(189). Biff does not take an effort in math but gets answers from Bernard in the examination. Willy considers it justified for Biff to take advantage of others and even encourages Biff's cheating in the exam. At the same time, Willy laughs at hard-working Bernard as a worm and being not liked. In this way, Biff flunks his math and fails to graduate though there are three universities begging for him (216). What's worse, Willy even justifies and encourages Biff's theft! He finds excuses for Biff when he knows Biff steals the ball from the locker room and even encourages the sons to steal the sand and lumber to rebuild their front stoop. The consequence is that Biff, a promising football star at school, steals himself out of every good job since high school (250) and steals Oliver's fountain pen when waiting to see Oliver have a new start. Biff is broke and desperate and can not bring any pride to the family. Happy can never bring hope to the family for his frequent lousy things with women. Clearly, Willy is not successful in raising his sons to be successful men.

Ben's first appearance centers on Willy's failure in doing his job of parenting, while the second appearance of Ben is on his failure in doing his job as a salesman. Ben appears after Bernard fires Willy. In this conversation, Ben says he buys timerland in Alaska and invites Willy to look after things for him. He tells Willy: "There's a new continent at your doorstep, William. You could walk out rich"(217). Willy likes the idea. What's more, he fits for the work which is a be evidently seen in Biff's recall of the nice days after

Copyright: (c) 2021 the Author(s). This article is an open access article distributed under the terms and conditions of the Creative Commons Attribution (CC-BY) 4.0 license (https://creativecommons.org/licenses/by/4.0/). Published by Al-Kindi Centre for Research and Development, London, United Kingdom. 
Willy's funeral "...or on Sundays, making the stoop; finishing the cellar; putting on the new porch; when he built the extra bathroom; and put up the garage....there's more of him in that front stoop than in all the sales he ever made"(255). Charley confirms that " He was a happy man with a batch of cement"(255). It is true that the Lomans are interested in and good at outdoors, but Willy turns down Ben's proposal in the second meeting. Linda dislikes it. What's more, the couple believes Willy will be a member of the firm in which he works for the old man Wagner. But it turns out to be an irony. Willy is fired by the young boss Howard whose name is even made by him. But the more important reason for Willy to refuse Ben is Willy's illusion of becoming a successful salesman like Dave Singleman who can make his living by calling his buyers at 84 without leaving his room. Willy decides to get rich in the city as a salesman, but he fails and is fired.

But there is a question. Why Willy follows Ben's ideas in the first meeting but refuses Ben's invitation in the second one? Isn't Ben a guiding role in Willy's world? I think Ben's words in their conversation are coined and selected by Willy himself. He chooses to recall or reveal the information he needs. He needs to justify his deeds in his parenting and his career choosing. So in the first meeting, he uses Ben's success in the jungle to justify the way he brings up his sons. And in the second meeting, he refuses Ben's proposal and so he eloquently persuades Ben and himself (more importantly to himself) that what he persists in is true. He concludes " we'll do it here, Ben! You hear me? We're gonna do it here"(217)! At this time, he expressed his sentiments about his dream of a successful salesman with great eloquence and Ben becomes a listener with few sentences to respond. Willy's dominance in the conversation is more obvious in the late two meetings.

The third time for Ben to appear is when Willy is planting seeds after he is deserted by the brothers in the restaurant. In the restaurant, Biff would like to tell the truth to his father while Willy hopes for him to have something promising. When he is informed that Biff steals Oliver's fountain pen when waiting to see Oliver, he is getting desperate. He does not think Biff has chances and he is decisive to commit suicide. Willy decides to kill himself for he thinks it can leave 20,000 dollars to Biff, but he also worries whether the insurance company will honor the policy and whether his sons, Biff especially, will despise his way. "You don't want to make a fool of yourself. They might not honor the policy" "It's called a cowardly thing" "He will hate you"(246-247). All these doubts are raised by Ben on behalf of Willy himself. They are Willy's worries and anticipation of Biff's reaction to his deed. Ben functions as another Willy who says no to Willy's decision. Willy hesitates to kill himself and he is not determined till the fourth appearance of Ben.

Ben appears for the fourth time after Biff's confrontation with his father Willy. According to Terry W. Thompson, at the age of sixtythree, at a time in his life when he should be able to offer sage and mature counsel to Biff, Willy remains simplistic and superficial, well-intentioned and caring, yet still woefully ignorant of almost all things, even his own allusions (Terry 2003). But, unlike his father, Biff has a sudden insight into his own life after he runs down eleven flights with Oliver's pen in his hand."What the hell am I grabbing this for? Why am I trying to become what I don't want to be (250)?" At that moment, he decided to face his own interests. And he decides to tell the truth to his father. "I am not a leader of men, Willy, and neither are you" (251). He cried "Will you take that phony dream and burn it before something happens (251)? It shocks Willy but at last, Willy realizes Biff loves him and forgives him so he is more decisive to die to get the money for Biff from the insurance company. So the last time Ben appears with more direct and encouraging statements to push Willy to commit suicide. "The jungle is dark but full of diamonds", "A perfect proposition all around", "Best thing"(252-253)! Ben's confirmation and urge are exactly Willy's determination. He is determined to die now for the benefit of the family. Li relates his suicide to the American dream in arguing that Willy is on the brink of a mental breakdown, but the American dream is so rooted in his mind that he still wants to make a final struggle to make a fortune with his death to show his worth as a man (Li 2006). Willy believes that a man needs to bring something to the family and his death is worthwhile if it can bring 20,000 dollars to Biff, though the actual chances for his sons to get the money are slim. Willy's suicide means he, in order to help out the family, is ready to take an adventure as his brother Ben does in the jungle.

Sister M. Bettina says that Ben is the most important minor character though he is dead before the play begins (Bettina 1961). Ben is important and he appears at key points when desperate Willy needs to find answers. But he is only the projection of his brother Willy's consciousness rather than an individual human force. What he says is exactly what Willy is conscious of and eager to tell. It is Willy who dominates their later three conversations, especially the latter two in which Willy speaks much more. Ben only urges Willy to do it when Willy decides to commit suicide in the last time. So it is Willy who decides what Ben says in the conversation and Willy gets determined to end his life by himself via the conversations.

\section{References}

[1] Bettina, M. (1961). Willy Loman's Brother Ben: Tragic Insight in Death of a Salesman. Modern Drama,4(4),409-412.

[2] Harrington, G (2006). Galloping Ghosts in Death of a Salesman. ANQ: A Quarterly Journal of Short Articles, Notes and Reviews, 19(1),58-59.

[3] Li B (2006). Struggle in Pain and Desperation: An Analysis of the Tragic Image of Willy Loman in Death of a Salesman. Cross-cultural Communication, 2(1), 62-65.

[4] Miller, A. (2006). Collected Plays, 1944-1961 (Vol. 163). Library of America.

[5] Ribkoff, F (2000). Shame, Guilt, Empathy, and the Search for Identity in Arthur Miller's Death of a Salesma. Modem Drama, 43(1),48-55.

[6] Thompson, T. W. (2003). The Ironic Hercules Reference in Death of a Salesman. English Language Notes, 40(4),73. 